\title{
Globalization, trade, and material culture: Portugal's role in the making of a multicultural Europe (1415-1806)
}

\section{Tânia Manuel Casimiro}

To cite this article: Tânia Manuel Casimiro (2020): Globalization, trade, and material culture: Portugal's role in the making of a multicultural Europe (1415-1806), Post-Medieval Archaeology, DOI: $10.1080 / 00794236.2020 .1750239$

To link to this article: https://doi.org/10.1080/00794236.2020.1750239

\section{Published online: 01 May 2020.}

Submit your article to this journal 준

凹 Article views: 37

a)

View related articles

View Crossmark data 
GEOFF EGAN MEMORIAL LECTURE 2019

\title{
Globalization, trade, and material culture: Portugal's role in the making of a multicultural Europe (1415-1806)
}

\author{
By TÂNIA MANUEL CASIMIRO
}

\begin{abstract}
SUMMARY: In the Early Modern age, Portugal was among the first European countries to engage in overseas trade and colonial ventures. The influx of new people and things rapidly transformed it into a multicultural country in permanent contact with the rest of Europe and the wider world. While we possess a vast amount of knowledge describing the overseas contacts and acquisition of goods from historical documents, in recent years archaeological excavations have begun to reveal direct evidence of these interactions. This includes thousands of people and objects such as ceramics, ivory and stone artefacts produced in overseas territories in Africa, South America and Asia. They were exported in vast amounts to several European countries, and are frequently found in archaeological excavations. These commodities were in part responsible for changing European perceptions of the world, its dimensions and cultural plurality. They also rapidly left their mark on European goods production, leading to changes in aesthetics and the introduction of new forms. This paper will discuss some of these objects in terms of how they reflect an Early Modern globalized world, and their influence on European daily life.
\end{abstract}

\section{INTRODUCTION}

During the 16th century, the world was transformed into an increasingly elaborate network of contacts and 'the world of trade began to transform the world of goods', ${ }^{1}$ based on the navigation of new or preestablished maritime trade routes, in which some commodities played important roles. Although this paper focuses mostly on the archaeological interpretation of material culture, manufactured goods on their own rarely played the most important role in this world system. Rather, relations, people and ideas did.

This paper focuses on a long period of analysis when so many different political, economic, social and cultural changes occurred with serious implications on material culture. Longue durée approaches are never easy and seldom tried in historical archaeology interpretation. An economic reading of Portugal during this period has revealed that the country has an exponential growth in the 16th century, declining in the first half of the 17th century and then stabilizing in the 18 th century. ${ }^{2}$ The archaeological record can in fact concur with this historical analysis. Except perhaps for porcelain, which was one of the most common goods imported from the East to the rest of the world, the main goods traded around the globe were not manufactured. Slaves and raw goods such as sugar, spices, fish, cotton, wood, salt, tobacco, cocoa, wine, and olive oil were typically the main cargo.

All countries have a different way of conducting historical archaeology and dealing with their own impact on globalization ${ }^{3}$ and this paper may be 
criticized for being somewhat too Eurocentric, even though trade with other parts of the world in Early Modern times is approached. The idea that Europe was at the centre of a global economy in the Early Modern period is overstated, as the importance of other regions such as $\mathrm{Asia}^{4}$ was also fundamental. While acknowledging this bias, the results of this research are mainly drawing on evidence from Portugal or areas of the world in direct contact with it, and the impacts of its people around the globe. In this sense, rather than considering Europe as an epicentre from an interpretative point of view, this paper argues that Europe is as much a destination as a point of origin of commodities, thus allowing for the study of networks and connections from different perspectives.

It might be also pointed out that I am too focussed on empiricism and do not engage with theoretical debates. In my work, I have always privileged the study of relations between people and things and how they reflect the workings of different societies and cultures. However, as noted previously by those who have come to Portugal from abroad, and as this paper will demonstrate, the amount of objects found in Portugal produced within the country or imported in the timespan discussed by this paper (before the industrialization of production) is immense. Millions of artefacts unearthed from Early Modern levels of archaeological sites lie in stores in Portugal and possibly will never be recorded or even studied. It is first necessary to deal with this state of the raw data and become familiar with its typological variety and relative quantities across different sites, which I consider integral before venturing into interpretations and studies of commercial connectivity, identity, inequality, consumption, mobility, and relations. This is why I insist on publishing so much about specific archaeological sites within the country focussing on the monographic approach to their collections. The combination of all the information retrieved from these micro realities permits to comprehend macro evolutions.

The primary questions which I am interested in relate to why people wanted these commodities to the point of motivating the global circulation of things, and how structural changes occurred in the wake of international contacts that took place. Novelty, luxury, and social distinction are usually mentioned as the main reasons for such demand. However, there are some goods associated with these networks that are transformed from being considered luxury items to everyday objects enmeshed in the lives of Europeans across different social classes.

\section{THE HISTORICAL EVENTS}

Portugal is usually known as one of the main countries responsible for the early development of the globalization and colonization processes in the Early Modern period. This began in 1415 when the first
African city - Ceuta - was conquered, followed by Ksar es-Seghir (1458), Azilah (1471), and Tangier (1471). By 1482, Elmina castle was built in Ghana, and the establishment of other forts continued in tandem with navigation along the African coast. The 15th century ends with two major events: in 1498 Vasco da Gama discovered the maritime route to India and two years later Pedro Vaz de Caminha led a fleet that reached Brazil; and in 1492 Cristobal Colon, under the Spanish crown, which was also seeking to encompass the globe, had reached the Antilles. Spain and Portugal were essentially alone, despite a few French and English attempts, in pursuing world navigation until early 17 th century when the English and Dutch initiated their own global maritime endeavours. All these events defined the 15 th century as a transitional period when global interactions were already occurring, although medieval mentalities continued to define ways of action within and outside the respective countries.

Settlements were founded in several parts of this new world and by late 16th century Portugal had established contacts with a large portion of the known world including India, China (a trading post in Macau founded in 1557), and regular contacts with Japan (1543). Overseas occupation endured until 1999 when Macau was 'returned' to China, although many of these occupations failed in the long term, with settlements abandoned or lost in military action. Brazil became independent in 1822, Indian settlements were lost in 1961, and by 1974 the remaining African colonies gained their independence. The original global network had by then fully collapsed.

During this period of more than 500 years, Portugal was not only influenced by its external contacts but its internal events also played a fundamental role, especially the period between 1580 and 1640 when the lack of an heir made Philippe II of Spain king of both Portugal and Spain, with the unification of both crowns. Philippe was the cousin of King Sebastião of Portugal, making him one of the heirs to the crown. Three Spanish kings occupied the Portuguese throne until 1640, when a Portuguese king regained the crown. During this 60 year period, although Portugal was in conflict with all the enemies of Spain, including England, it had direct access to other markets, especially in South America and the Pacific. It is possible that this contact with territories under Spanish dominion already existed before 1580 , since marriages between the Portuguese and the Spanish crowns occurred regularly since late 15 th century. Another major political event occurred in 1806 when the French invaded Portugal, leading the royal family to flee to Brazil and rule the 'empire' from across the ocean.

On both occasions, support to get rid of the Spanish and the French was provided by the English. This resulted in a mutually beneficial political (and economic) relationship between both countries, and 


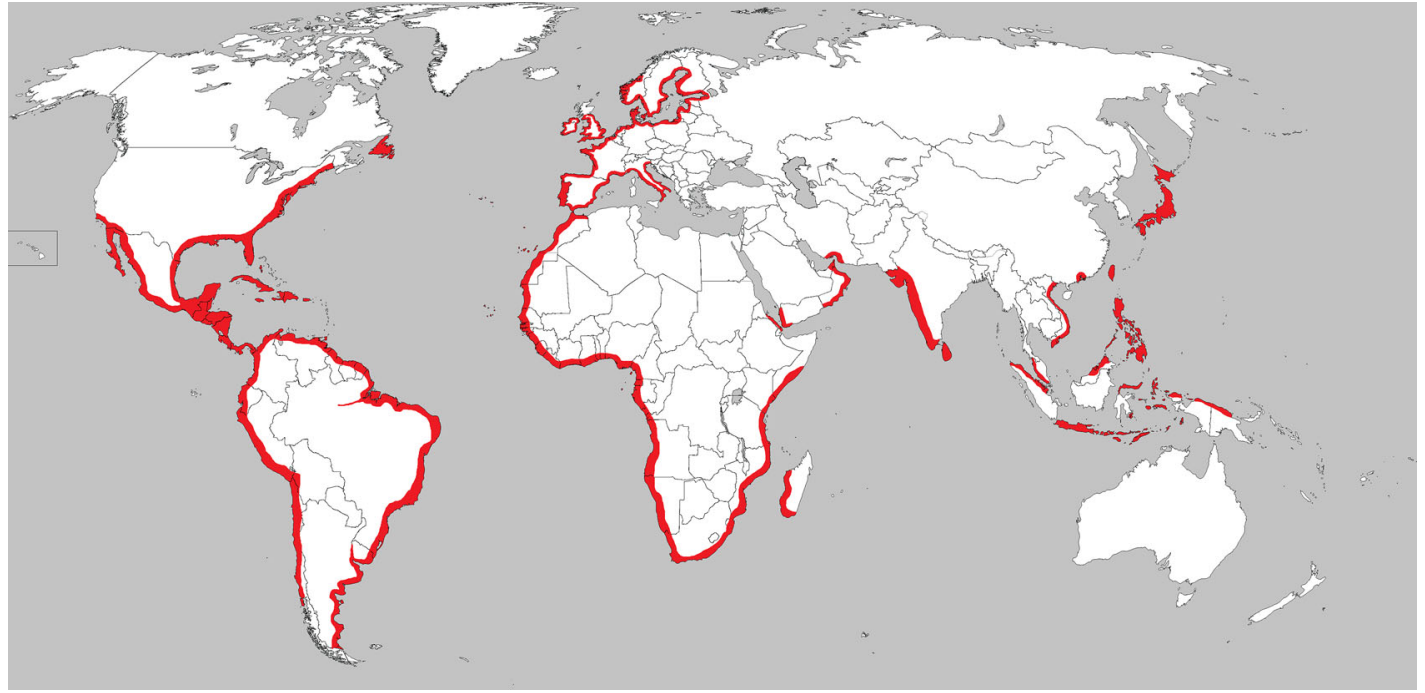

FIG. 1

World map with the areas with direct or indirect contact with Portugal.

the 'oldest alliance' in the world, going back to the 12th century, left marks on the Portuguese economy and even in the number of settlements that Portugal had around the world. For example, the marriage between Charles II and Catarina of Braganza in 1662 (daughter of the Portuguese king) allowed the English to acquire Tangier and Bombay as part of her dowry. Several trade treaties established a connection between both countries, the Methuen Treaty (1703) being particularly significant, as a result of which the English became major consumers of Portuguese wine while Portugal imported English wool. ${ }^{5}$

These political events were fundamental in the history of Portugal but not the only ones to leave profound marks. On November 1st 1755 a huge earthquake destroyed most of the southern part of the country, with Lisbon and surrounding cities being the most affected. It took Portugal more than a century to be fully rebuilt. While the event was highly impactful at that time, killing thousands of people, it continues to be significant from a historical and archaeological perspective. This major event, usually recognizable in every urban archaeological excavation in Portugal, tends to mark the end of 'historical archaeology' in Portugal. ${ }^{6}$ Until recently, archaeologists did not pay much attention to contexts dated after 1755 , although today interest in them is increasing. ${ }^{7}$ In this sense, archaeology in Portugal has relatively recently started to study archaeological contexts after the mid-18th century and discover their significance, for the country was still fully committed to global contacts from China to Brazil during this time. The turn towards archaeology of this period will help redress the lack of secure interpretations and knowledge of the impact international contacts had in Europe at the time, and the role Portugal played therein.

\section{GEOGRAPHIC LAYOUT}

Considering the navigations that occurred from 1415 to 1999 , Portugal was in contact with all the known world (Fig. 1). While in some parts the Portuguese founded permanent settlements and occupied territory with political plans to increase and maintain that occupation, as exemplified by Brazil and the Atlantic islands, others followed a different strategy, being simply coastal commercial settlements used to acquire inland commodities. These goods were then introduced into a broader a world system of trading networks.

While not all overseas territories were exploited in the same way, all of them nevertheless played a key role in this process. From Africa, people were the most important 'commodity', evinced by the forced movement of thousands of human beings. From South America, precious metals, animals and plants - such as turkeys, potatoes, cocoa and corn -, among other products, were key in changing European food habits. From Asia, plants (mostly spices), ceramics and semi-precious stones featured strongly in European households from early 16th century, influencing the production of tableware and dining habits. Thus, objects and people from different regions around the world reached Portugal on a regular basis and were redistributed thence to other parts 
of Europe and the world. This occurred mostly in the 16th century, since competition from other European nations was rare until late $1500 \mathrm{~s}$.

Evidence of what was being brought and how the Europeans reacted to these new things is found in archaeological contexts and supported by written evidence, especially port logs and probate inventories. This paper will focus primarily on archaeological testimonies, not just imports into Portugal but how commodities arriving through overseas contacts were sent to other parts of Europe or the world, taking these cultural influences with them.

This system of world contacts increased the circulation of things and people reaching and leaving Europe, creating different ontologies, influencing societies and developing an increasingly multicultural world. The new global system, completely established by the mid-16th century, had attracted a considerable number of migrants into Portugal, most of them traders originating from England, Italy, and Spain, among other places. Documentary evidence of their presence is abundant and communities of foreigners were established in different cities, especially Lisbon and Porto, ${ }^{8}$ not to mention their presence as sailors on boards Portuguese ships sailing in the Atlantic and Indian Oceans.

\section{FROM THE WORLD TO PORTUGAL AND TO EUROPE}

All of these world contacts endured from more than five centuries and connected Europe, northern and Sub-Saharan Africa, South America and Asia. They were the basis for the development of a multicultural country, especially in the largest cities and those connected to overseas trade. In this sense, Lisbon, Porto, Lagos, Coimbra, Aveiro, and Setúbal, among others located on the Atlantic seafront received a steady stream of commodities from the colonies. The traditional study of non-European influences in Europe from an archaeological perspective has and continues to focus mostly on high-value commodities (especially ceramics, ivories and spices) brought from overseas markets and how Europeans consumed them. The research emphasizes exclusively the impact these had in Europe from a trade and social differentiation point of view.

Portuguese navigation around the world allowed Portugal to become the first country in Early Modern Europe to receive large amounts of non-European commodities. One of the earliest and most frequent imports was people. Despite the complexity of defining this, according to historical data, Portugal was the first nation to enforce the mobility of thousands of people into Europe in the Early Modern period, ${ }^{9}$ redistributing them across different European countries. ${ }^{10}$ This role is even bigger when we consider all the human beings forcedly deported into the New
World to work in sugar plantations that never reached Europe. This human trade brought wealth to the crown and country and allowed the Portuguese to assert their domination over the global economy. ${ }^{11}$ The study of this through archaeology will necessarily have to engage with issues relating to societal problems and global challenges, ${ }^{12}$ especially if we consider the impact such human movements continue to have in Europe today.

The majority of non-Europeans living in Portugal in the Early Modern period were slaves from Africa, South America or Asia, although black Africans were the majority. It is not possible to ascertain how many entered Portugal between 1415 and the official abolition of slavery in all Portuguese territories in 1869 . However, accounts of slaves' presence in cities such as Lisbon mention thousands of people, up to $10 \%$ of the population in the 16th century. ${ }^{13}$ These numbers will always be difficult to define, especially since not all the slaves in the country were 'imported' and a large number was already born in the country, leading to an increased number of Portuguese-born slaves in the 17 th and 18 th centuries. This number only started to decrease in the second half of the 18th century. In 1761, a law determined that all black people brought from Africa, America and Asia were considered free, exception made to the ones who returned in 1822 from Brazil. Two years later the law of the 'free womb' was passed and children born from slaves in Portugal were given the status of free individuals.

Some of the earliest non-Europeans were brought from North Africa in the early 15th century as Moorish slaves, though their presence in the archaeological record is still not confirmed. ${ }^{14}$ These slaves were frequent in Spanish territory. There are records from 1444 of the first mass importation of black African slaves entering the city of Lagos, possibly the first time that Sub-Saharan African people were brought as cargo into Europe. ${ }^{15}$ In 2009, an archaeological excavation in Lagos discovered about 155 individuals in a mass grave with no signs of ritual inhumation. ${ }^{16}$ This group has been studied using DNA analysis and physical anthropology, and the majority of them have been confirmed as having African ancestry. ${ }^{17}$

Evidence of non-European populations found in Portugal is not rare, although studies in the subject are just starting to be developed. In Sines, evidence of dental modification in a male individual has led bioanthropologists to postulate that he could be African, although we cannot determine whether free or enslaved, especially since he was buried with a pouch containing some coins. ${ }^{18}$ In Loures, the excavation of an Early Modern cemetery dated to the 17th and 18th centuries yielded several individuals of possible African origin, as suggested by their dental modification and physical characteristics. ${ }^{19}$ Contrary to all other known evidence which originates from 


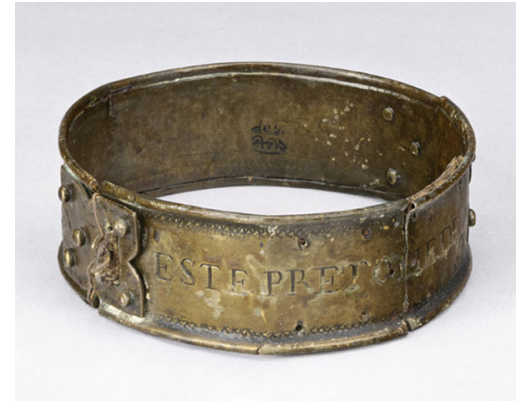

FIG. 2

Slave collar (courtesy National Museum of Archaeology).

urban centres, this is a rural site and if these African individuals were slaves they were probably forced to work in physically demanding agricultural activities, as evinced by pathologies found on their bones. ${ }^{20}$ Although a recent excavation this is fundamental evidence in the study of African individuals in Portugal since these human remains reveal the everyday lives and the way slaves were treated.

Slaves were also brought from Asia and India but in lesser amounts and trade of them was forbidden still in the 16 th century, ${ }^{21}$ making them less easily recognizable in the archaeological record. The role of the enslaved population in Portuguese society and culture and the impact they had in the development of the country is in serious need of historiographical analysis, although their presence and impact on modern society was recently approached from an archaeological perspective. ${ }^{22}$ The study of slavery is still a delicate debate in Portugal and one that most scholars are not yet ready to initiate, especially when it comes to acknowledging the responsibility of Portugal in the transatlantic African slave movements or the role of Africans in Portuguese territory. ${ }^{23}$ Portugal seems to have been the only country that developed a model of colonial exploitation within Europe, with thousands of African slaves used in urban and rural areas although used in activities not related to plantations. While the human remains of African slaves have been found in the Canary Islands, Spain, the territory was known for its sugar plantations and following the same exploitation model as South American territories. ${ }^{24}$ Portugal, on the other hand, was a unique case in Europe and these human contacts created a specific type of society. While this has already been acknowledge from historians, archaeologists still have to initiate a debate that goes beyond empiric evidence.

Although human trade into Europe was one of the most impactful and lucrative engagements of Portugal's overseas ventures, it was certainly not the only source of profit. Around the mid-15th century, archaeological sites start to show signs of the early contacts with the appearance of African ivories, known in the literature as 'Afro-Portuguese'. These objects are the first artefactual manifestation of contacts between Europeans and Africans from places such as today's Sierra Leone or Benin. Their artistic and aesthetic features made them highly desirable and valued in Europe, where they were often sent to noble houses via Lisbon. The German artist Albrecht Dürer (1471-1528) mentions in one of his diaries the acquisition of two salt cellars from Sierra Leone in Antwerp in 1520, which he most likely bought from Portuguese traders in Flanders. ${ }^{25}$ Each of these ivory objects tells a story of people's identities and how they influenced European populations. Although such objects are widely known and published in museum collections, they have always been treated through art historical perspectives and not as testimony of colonial encounters. Portugal has a considerable amount of such objects found in archaeological contexts, mostly among domestic refuse from the late-15th to the 19th centuries, demonstrating that, contrary to what was happening around Europe where these objects were being kept in display cases, in Portugal they were an active part of daily household activities. ${ }^{26}$

Other objects originating from these world contacts have been found in Portugal, although their commercial value seems to have been significantly lower. Several contexts dated to the same period have yielded objects dubbed as 'African pots', usually associated to African populations living in Lisbon. Recent archaeometric analysis has revealed that these were not made using Portuguese clays. Their production techniques, coil hand built, and morphology does not correspond to anything made in Europe, not even in the Canary Islands where contemporary pots were also hand made. They present the traditional African 'bag-shaped' form and flat base. When the origin of these pots is confirmed, it will be possible to assume that some African people living in Portugal might have originated from the same places. Since they seem not to have had a commercial value, it is difficult to explain their presence. Were they used by African populations and if so how were they acquired? ${ }^{27}$

One of the most impressive artefacts relate to slavery are the slave collars (Fig. 2). Two of them belong the National Museum of Archaeology stores and their use was not just kept slaves arrested they were a sign of ownership. They have engraved the name of the slaves' proprietor. 'Este preto pertence a Agostinho de Lafetá do Carvalhal de Óbidos' (This black man belongs to Agostinho de Lafetá from Carvalhal de Óbidos) and 'Este escravo pertence a Luiz Cardozo de Mello morador em Benavente' (this slave belongs to Luiz Cardoso de Mello who lives in Benavente).

Exotic animals and plants were key targets in Early Modern Portuguese trading ventures. When 

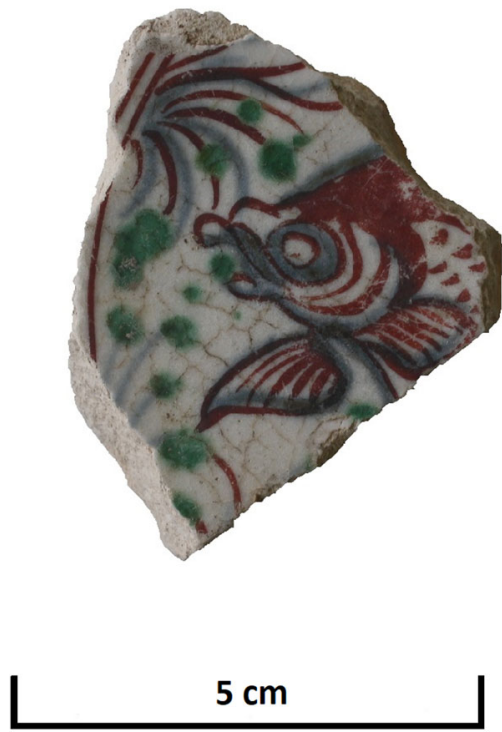

FIG. 3.

Fragment of Vietnamese plate found in Alhandra (courtesy Museu Vila Franca de Xira).

Portuguese sailors reached overseas territories, the local fauna made a considerable impression on them. Some were brought to the country as attractions, attested in literature and even paintings but have never been sought in the archaeological record. In 1500, when Pedro Álvares Cabral reached Brazil, one of the things that most impressed him were parrots. Portuguese sailors had similar reactions to other animals they encountered in Africa and the East. Elephants and rhinoceroses were brought to the country as curiosities (an instance of them involved in a staged 'street fight' in Lisbon in 1515 is recorded), ${ }^{28}$ while others were bred. Turkeys, originating in Central America and imported to the Iberian Peninsula in the early 16th century, have been found in contexts associated with quotidian household activities, ${ }^{29}$ clearly remains of food consumption.

The same can be said about plants, especially spices, which entered the country in early 16 th century and just a few decades later changed the way people consumed food. ${ }^{30}$ Studies of Early Modern zooarchaeological remains are only occasionally made in Portugal, yet this paucity of research is surpassed by the amount of stored excavated material. Thousands of animal remains are housed in archives across the country awaiting analysis in order to understand the impact that overseas navigation had on animal consumption within Portugal and greater Europe. The few researchers specializing in zooarchaeology in Portugal focus their studies mostly on prehistoric and Roman periods, while medieval and post-medieval collections suffer from a serious paucity of research. Occasional studies have been made but mostly of small collections. ${ }^{31}$

Plants, especially spices (e.g. pepper, cloves, cinnamon, among others) made an equally significant impact on Early Modern Portugal. They enter the country in early 16 th century and just a few decades later become the staple of recipes and are used on a daily basis. The few existing archaeobotanical studies are exclusively dedicated to prehistoric and Roman contexts and never post-medieval contexts. One exception is the monastery at Tarouca in north Portugal. $^{32}$ Except for this site, 16th-19th century archaeological sites have never been surveyed for plants, leading to a lack of collections. Evidence of these spices is frequent in Portuguese wrecks such as the famous Pepper Wreck ${ }^{33}$ and the Esmeralda, wrecked off the coast of Oman. ${ }^{34}$ As with animal remains, the study of plants from Early Modern contexts has been limited - a large number of samples have been recovered from various sites but never studied. Archaeobotanical research in several countries in Europe has provided evidence of spices used since the 16th century, some of them imported from the East by the Portuguese. ${ }^{35}$ The undertaking of archaeobotanical studies in Portugal itself would contribute significantly towards understanding Early Modern foodways and their relationship with the Early Modern global economy.

The further afield Portuguese ships sailed, the larger became the amount and variety of imported commodities. Portugal was the first country to import Chinese ceramics, distributing them to wider Europe from the very early 16 th century. ${ }^{36}$ This monopoly only ended in early 17th century when the Dutch and the English reached the Indian Ocean. ${ }^{37}$ Different countries developed different consumption patterns and while Chinese porcelain was a luxury in every other European country in the 16th century, in Portugal it was consumed by various social groups from nobles and clergy, found in palaces and female convents, ${ }^{38}$ to more modest households. ${ }^{39}$ It has also been found in rural areas where consumption was expected to be low, although hundreds of artefacts have also found in these non-urban contexts. ${ }^{40}$ Chinese porcelain was widely available and widespread a consumption which endured until late 19th century.

Blue-on-white Chinese porcelain was one of the most fashionable items in the 16th and 17th century although not the only eastern ceramic product to reach Portugal. Pots from Thailand and plates from Vietnam have also been found in archaeological contexts (Fig. 3). ${ }^{41}$ Portugal was the first country to import large quantities of Chinese porcelain and sell it to other countries as early as the beginning of the 16 th century. Although these objects are not evidence of direct presence of non-European populations in Europe, they were fundamental in the development of new aesthetic European style influencing 

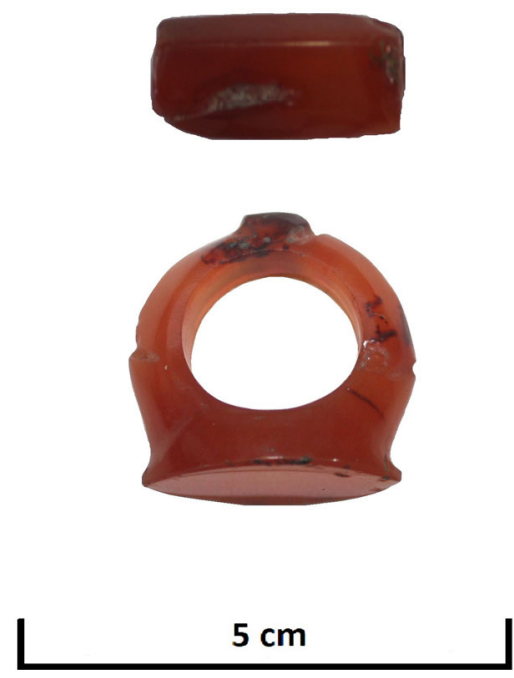

FIG. 4.

Cornelian ring and bead found in Campo das Cebolas, Lisbon (courtesy Cláudia R. Manso).

households' consumption habits and associated material culture during the Early Modern age. Countries such as Portugal, Spain, England, France, and the Netherlands began to decorate their pottery following Chinese porcelain styles in a clear cultural appropriation. ${ }^{42}$ This imitation continued for centuries and whilst symbols and overall iconography depicted on plates and bowls produced in Europe lost their original meaning, they gained new ones as signs of exotic relations and global contacts. The production of ceramics in several places of Europe which had strong connections with distant ceramics-producing locations reveals how the impact of trade of globalized goods was not only economic but cultural enough to transform semiotic interpretations. Although Chinese ceramics and spices were the most important commodities brought from the East, other objects have been found in archaeological contexts. Asian ivories are rare but occasionally found in wrecks and archaeological sites, especially parts of religious figures such as the Madonna and the crucifixion. ${ }^{43}$

Semi-precious stone objects acquired in India are more frequent finds and in several contexts. In Lisbon, at a riverfront excavation of an early 16th century context, several carnelian beads and rings were found (Fig. 4). ${ }^{44}$ These same objects have been recovered from across the country in places such as Almada and Algarve. ${ }^{45}$ Similar objects were found in the remains of the Esmeralda, the aforementioned ship wrecked off the Oman coast in 1503 on its way back to Portugal. ${ }^{46}$

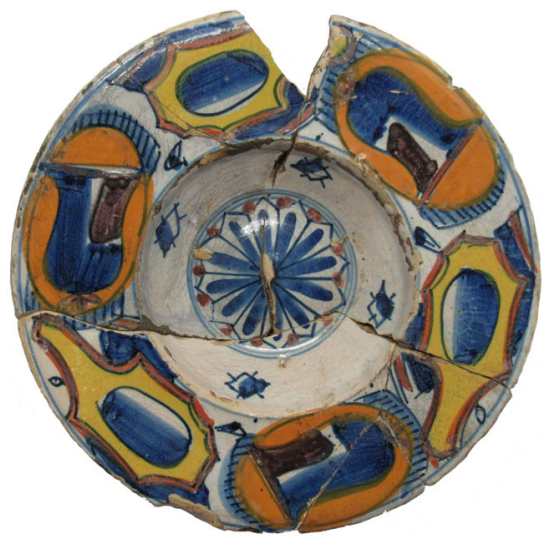

FIG. 5.

Italian Montelupo dish found in Campo das Cebolas, Lisbon (courtesy Cláudia R. Manso).

It would be imprudent to believe that this process of global contacts affected Portugal exclusively. The country was directly or indirectly in permanent contact with the known world, leading to wide circulation of products, people and ideas. This contributed to the creation of a multicultural Europe, one of the most identifiable aspects of European society today and fundamental to the way European communities respond to current challenges.

\section{FROM EUROPE TO PORTUGAL}

The trading system that connected Portugal to Europe was based not only on commodities which were acquired overseas but in Portuguese products as well. Wine, olive oil, salt and fruit were the primary goods transported to Europe. In return, Portugal received products from different nations, with wood, textiles and animal products being the primary desirables. Sometimes other products would enter the country and survive in the archaeological record, ceramics being the most abundant, either as containers or as valuable goods.

The quantity of ceramics from southern Europe (Italy and Spain) found in mid-15th to mid-16th century contexts is quite high. Though these have never been systematically studied, thousands of objects have been found across the country. Most direct trade was made with Liguria and Tuscany. The majority of objects found in Portugal seem to have been made in Montelupo and Pisa areas, although other areas cannot be ignored. Probate inventories and wills from the early 16th century mention the existence of Pisa pottery, ${ }^{47}$ the port where Montelupo ceramics could be exported. These were the traditional polychrome 

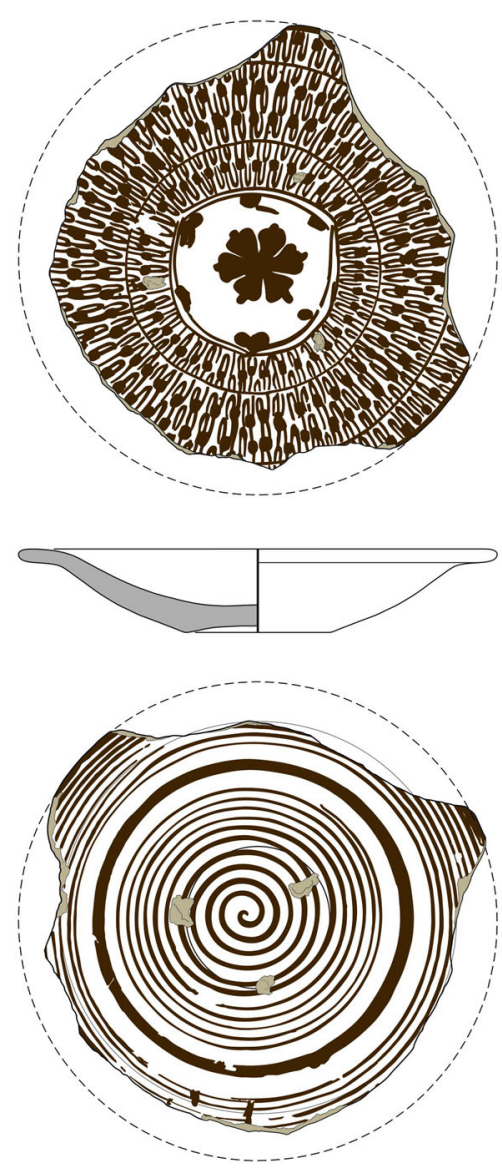

Lustreware bowls found in Rua do Arsenal, Lisbon (courtesy António Valongo).
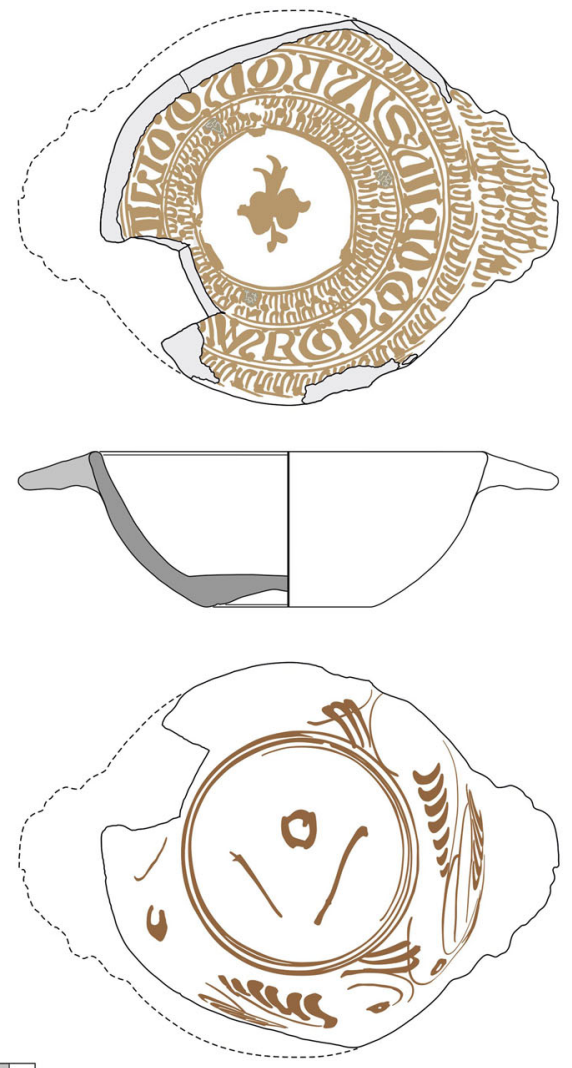

objects as well as the sgraffito wares decorated with recurrent motifs (Fig. 5). Later Italian objects are rare and just a few 17th century Ligurian objects have been found, most of them associated with wealthy sites such as the house of Prince Pedro, later king of Portugal. ${ }^{48}$

Italy was also a large supplier of glass objects, especially from Venice. These are also found in large quantities and decorated with various techniques although the most appreciated were the millfiori. ${ }^{49}$ Venetian glass also inspired Portuguese glass production, which imitated the Italian wares. ${ }^{50}$

As for Spain, the relation with its ports was always regular and in the late 15th and early 16th century Portugal received large quantities of Spanish ceramics, especially but not exclusively from Seville. These were mostly cuerda seca or lustreware objects, maintaining the tradition of Islamic pottery (Fig. 6). There is evidence of the production of tin-glazed wares in Portugal as early as the second half of the 15 th century, however these were plain white or with a blue line under the rim. ${ }^{51}$ Highly decorated objects are not known prior to 1570 s. Objects from other parts of Spain are less frequent although occasionally Talavera ceramics also appear in late 16th century contexts.

For years every sherd of blue-on-blue ceramics found in Portugal was considered either Italian from Liguria or Spanish from Seville. However it is now proven that Portugal itself was also producing large amounts of these ceramics, imitating the foreign wares. ${ }^{52}$ At this point it is still difficult to visually differentiate the three main ware types and determine if the objects found in Portugal were imported or produced in the country, making the real extent of this production not yet fully understood.

Ceramics and glass from other Mediterranean locales diminish in consumption and even cease in 


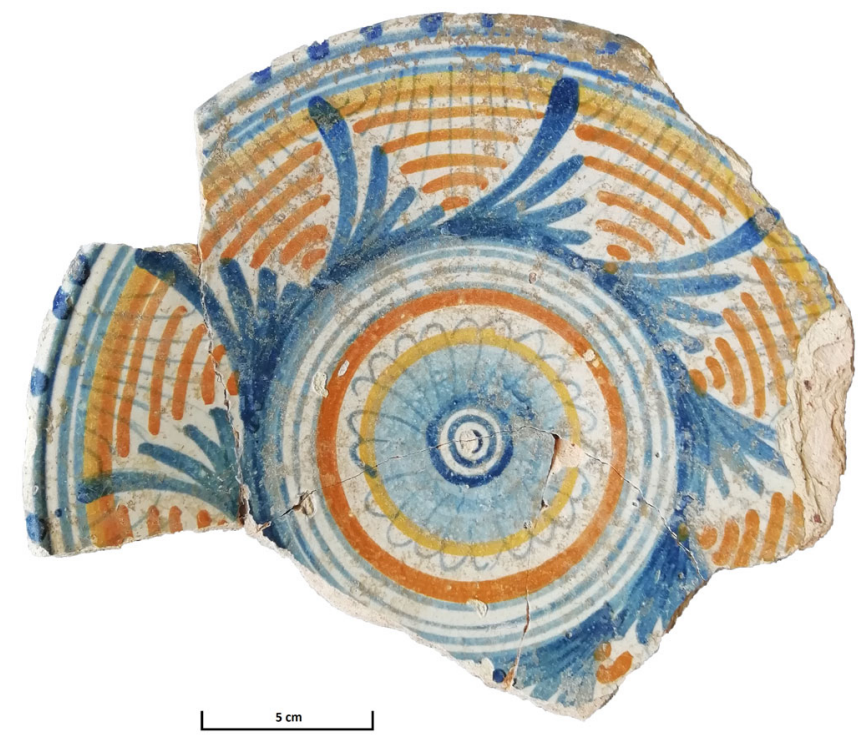

FIG. 7.

Dutch plate found in Mouraria (courtesy Vitor R. Sousa).

the first half of the 16th century. Examples are found discarded complete in dumps and landfills along the Lisbon riverfront formed during this period. The reasons for this discard seem to be related with the new massive influx of Chinese porcelain. Numbers are never easy to define but King João III decreed in 1522 that every ship sailing from India to Portugal could have up to a third of its cargo in porcelain, revealing the high amount of pottery that entered the country. ${ }^{53}$ As mentioned, porcelain was recurrent in Portuguese 'middle class' households and not just used by the nobility, making it a relatively accessible commodity.

Contacts with northern Europe happened on a daily basis, at least if we trust the port records. So far, French objects seem to have stopped being imported in the 15 th century, with the occasional Rouen platter found in later (e.g. 18th century) contexts, ${ }^{54}$ although they may be present in greater quantities and archaeologists are not yet able to identify them. The same cannot be said about Dutch imports. The trade between the Netherlands and Portuguese ports was constant. Ships sailing to between Dutch cities and Lisbon and Porto are recorded in port logs listing all types of commodities. Exports from Portugal were mostly salt, wine, olive oil and fruit, while the predominant import was wood. The archaeological record has also revealed imported ceramics such as majolica, faience and even clay pipe miniatures $^{55}$ demonstrating frequent contacts between both countries as early as the 16th century
(Fig. 7). Although these Dutch finds are present from the late 16th to the late 18 th centuries, the number seems to increase in the mid-1700s with blue-onwhite faience decorated with Chinese inspired motifs and floral decorations. These are found mostly in wealthy contexts. ${ }^{56}$

Although contact with Britain was frequent, British objects are quite rare in the archaeological record before the mid-18th century. As noted above, the political and ensuing mercantile alliance between both countries goes back to the 12th century with the constant presence of English merchants in several Portuguese cities, but artefacts brought from England are somewhat incidental until the industrial revolution, when Staffordshire ceramics flooded the Portuguese market in the 19th century. Once again, this trade was based mostly on other type of perishable and consumable commodities.

Port logs also confirm frequent contact with Germany, with ships sailing to and from Hamburg and Lübeck, among other cities, conveying all types of commodities. Imported goods were most certainly perishable since German objects are rare in Portuguese contexts. A few notable exceptions are stoneware jugs and tankards made in Frechen and Siegburg. ${ }^{57}$ These are the typical belarmine jugs and small white plates (Fig. 8).

Every once in a while a shipwreck is also found, which offers important evidence of the interactions discussed here. The cargo travelling on board a wreck found in Belinho off the coast of Esposende 

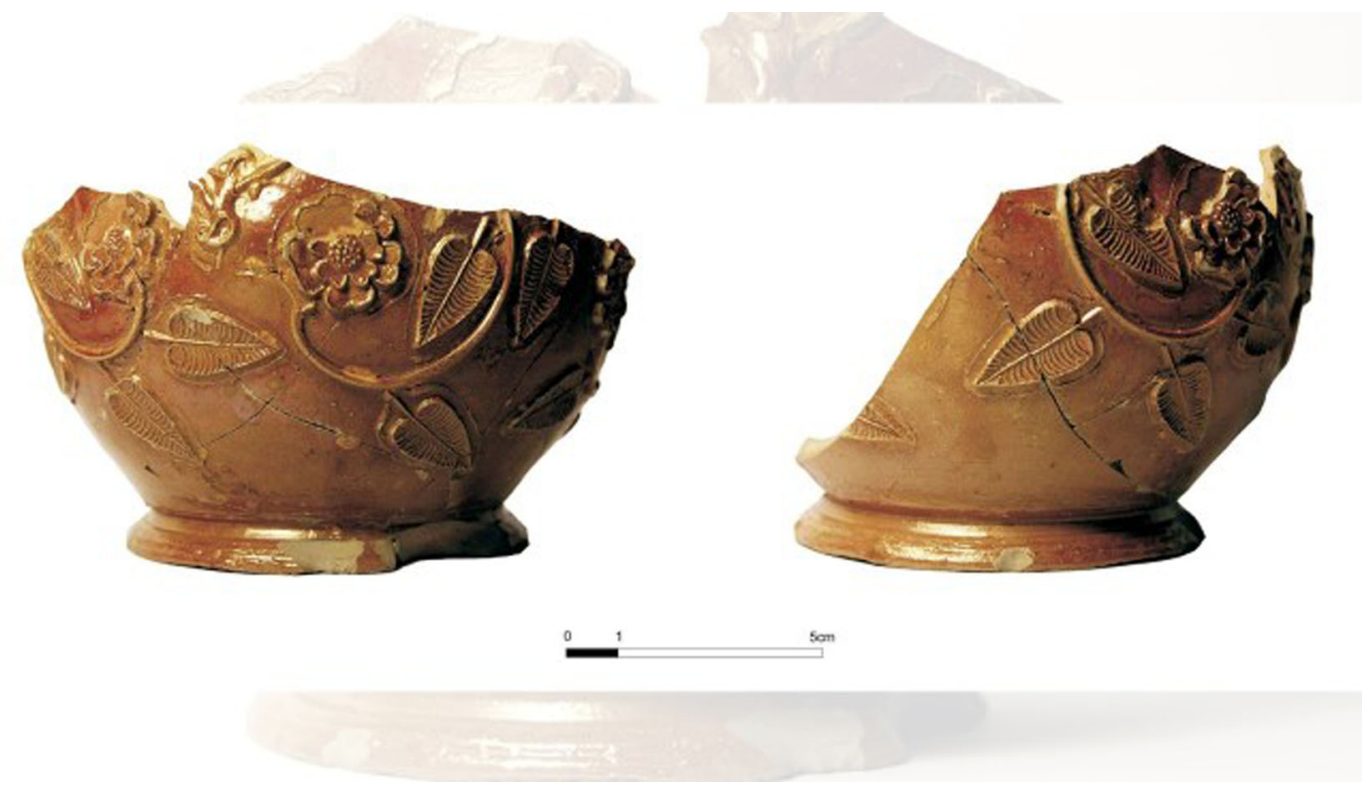

FIG. 8 .

Renish stoneware jar found in Lisbon (courtesy Márcio Martingil).

revealed the contacts between north and south Europe. Although the nationality of the ship is not known the study of its form, artillery and cargo may reveal a 1520-1560 date. Dozens of pewter objects and even tin plates, known as alms dishes produced in northern Europe were found (Fig. 9). We do not know if the final destination of these vessels was a Portuguese port, however, in spite of the fact that alms dishes are not found in the archaeological record, they are often mentioned in the inventories of churches and convents. ${ }^{58}$

\section{FROM PORTUGAL TO THE WORLD}

The role of Portugal as the head of a large overseas empire not only permitted it to become one of the most vibrant multicultural territories in the world, but made it a key channel for the export of such influences to the rest of Europe. The country produced several commodities which were in high demand not only in Europe but also other parts of the world. Salt was produced on an industrial scale and exported in large quantities to northern Europe, especially to England, Ireland, Sweden, the Netherlands and Germany, together with wine, olive oil and fruit. Together with these products, Portugal specialized in specific types of ceramics which were exported to several parts of the globe and recognized by their formal and aesthetic characteristics.
Two types of commerce have to be distinguished here: with trade partners and Portuguese colonies. Some regions had no political connection with Portugal beyond commercial. This was the case for all European countries (except Spain during 1580-1640) and their colonies. ${ }^{59}$ As for Portuguese colonies, they were considered an extension of Portugal's territory therefore a similar type of consumption was promoted, especially as settlers wanted to reproduce the domestic European environment in these new places.

As mentioned, salt, wine and olive oil were the most requested products. For a great part of the 16th century, Portuguese port cities served as commercial platforms for the transaction of commodities coming from African and the East, a role that was lost in the 17th century when the English and Dutch reached the Indian Ocean. Nevertheless, other products continued to be traded, particularly ceramics, for which Portugal was well known. By early 16th century, the country was already specializing in the production of louça d'água (water ware), which endured until the 20 th century. ${ }^{60}$ The property of some clays from specific parts of the country added a special smell and taste to the water consumed from these vessels, especially those produced in the High Alentejo region at Estremoz and Montemor-o-Novo. ${ }^{61}$ This earthen smell and taste made these objects appreciated in several parts of Europe and the New World, with discoveries in England, the Netherlands, Germany, and at 


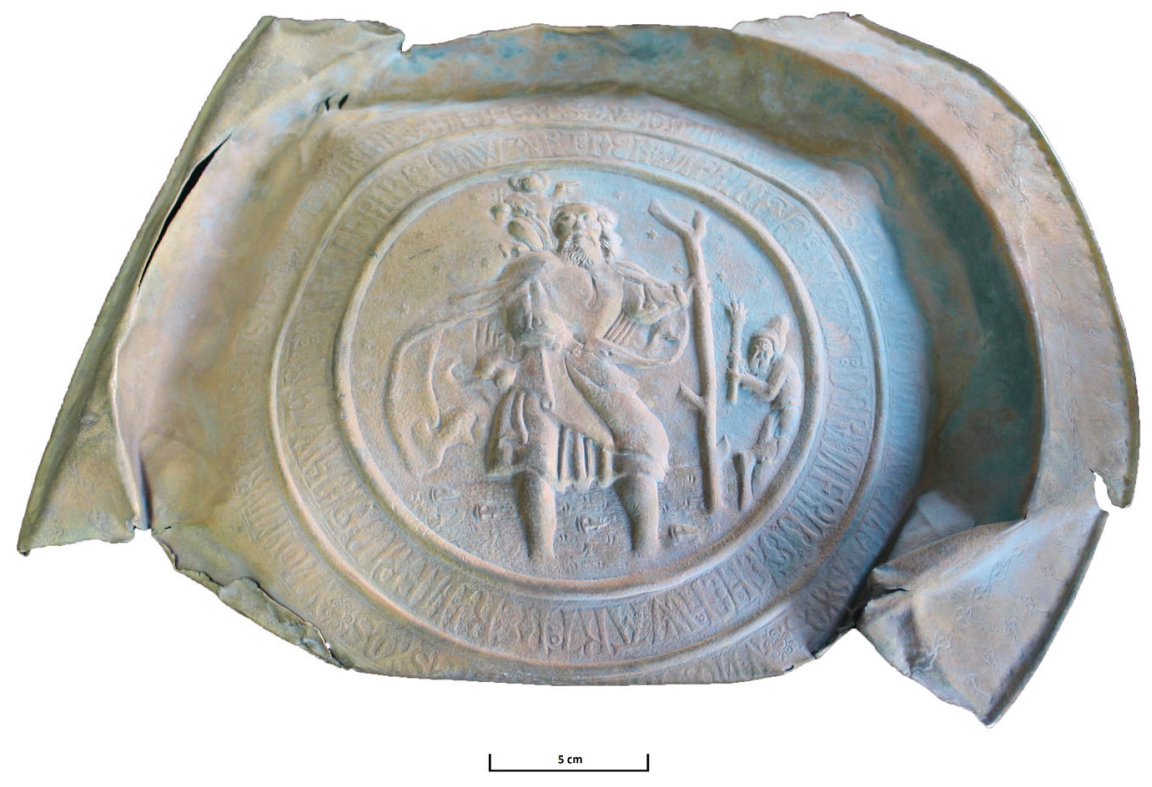

FIG. 9.

Almsdish found in the Belinho wreck, Esposende (courtesy Esposende Municipality).

several New World sites such as Jamestown and Ferryland. ${ }^{62}$

Tin-glazed ware was produced in Lisbon from the second half of the 15th century, however around a century later this ware starts to gain quality through a broader decorative repertoire, much inspired by a combination of Chinese porcelain and European influences. These products start to be designated as 'Lisbon porcelain' and are exported around the world in large quantities, satisfying a demand for eastern products. ${ }^{63}$ By early 17 th century, Coimbra and Vila Nova were already producing these objects. They were mostly appreciated in the Atlantic world where they are found literally everywhere European ships sailed and are mentioned in probate inventories. ${ }^{64}$ This type of product did not have a market in the Indian and Pacific Ocean, where Chinese porcelain had superior quality. A few objects are nevertheless still found in places such as India, Macau and even Japan.

This world trade of Portuguese ceramics starts to decrease in late 17 th century and by mid-18th century is only made with the colonies. The reasons for such decline are debateable and seem to be related to internal and external factors such as the emergence of new production centres in Europe and the changes in the demands of pottery from the European consumers. ${ }^{65}$ As for the other commodities, such as the aforementioned salt, wine and olive oil, they continue to be of international demand until the 20th century.

\section{CONCLUSION}

Portugal's port cities were some of the most vibrant international cities on the globe for more than 400 years, acting as fundamental arteries in a circulation system of people, animals, plants and things, and connecting several parts of the globe. Lisbon was not the only Portuguese city to develop that role and certainly Viana do Castelo, Porto, Aveiro, Coimbra, Setúbal, and Lagos, despite their comparatively smaller size, played significant roles in the world trade. All of this circulation of people and commodities made Portugal a multicultural country where different cultures and ways of life shared the same territory. This was mostly visible in port cities and less in the countryside, where foreigners may have also lived, although evidence is less easily recognized.

There is a general idea that the Early Modern age was a time in which the entire globe was in contact. This was not the case. In spite of the connectivity between coastal areas, inland territories on several continents were still outside of these networks. In countries where the interiors were deprived of rivers or accessible roads, globalization arrived late and material culture rarely reflects these world contacts. Even in Portugal, inland small cities, although an exception in the general panorama, will have to wait until late 18th century to have access to some of these commodities. 


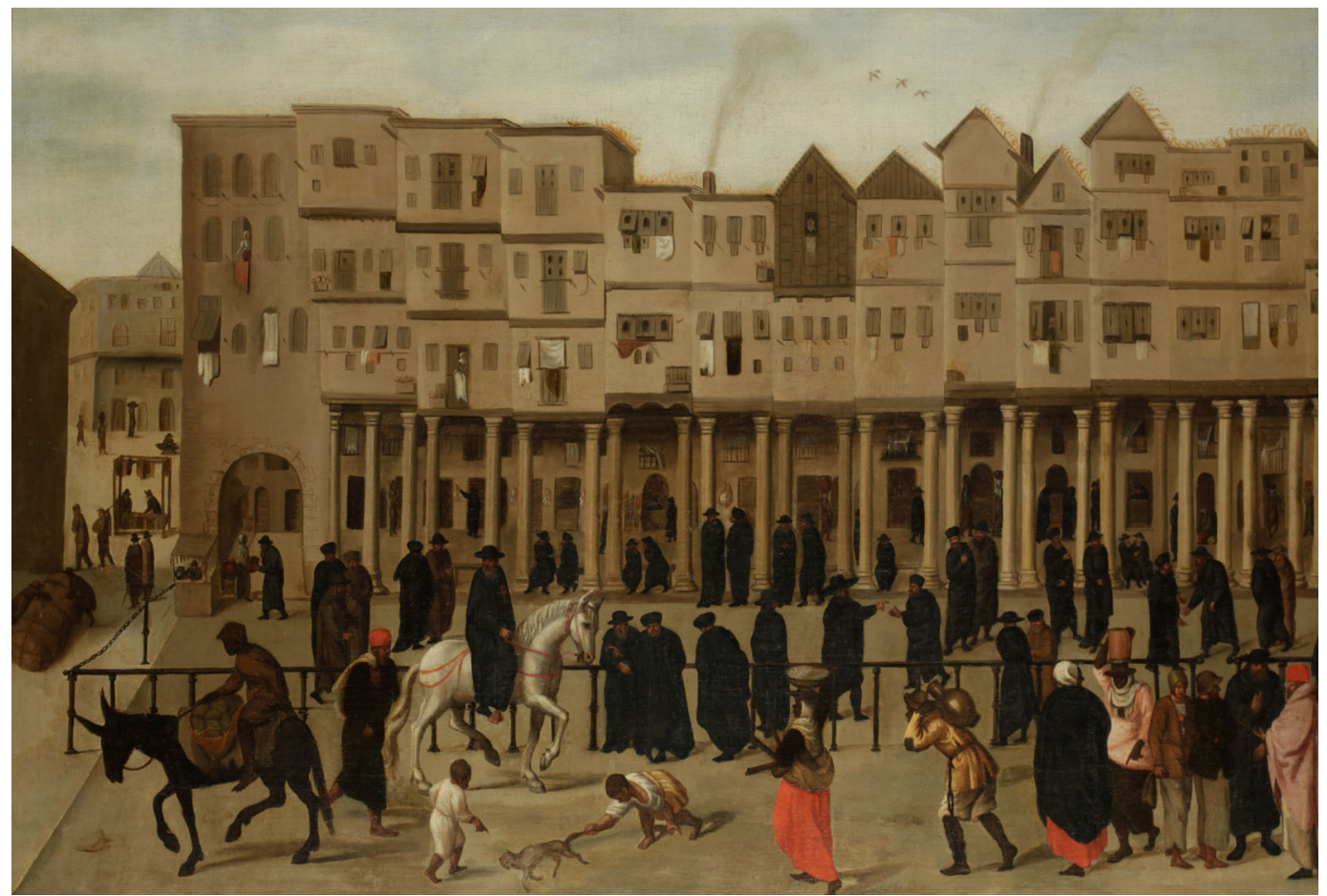

FIG. 10

New Merchants Street (courtesy Society Antiquaries London).

By the early 16th century, most of Portugal was already populated with people, exotic animals, smells and tastes from around the world. Even though some never left the country, Portuguese people were nevertheless enmeshed in all of these different ontologies to various degrees. Over time, people internalized a multiplicity of differences, understanding the diversity of a globalized world and creating a global identity that was also shared by other European countries in the following centuries. Permanent relations with most of the other parts of Europe guaranteed that this multiculturalism transcended borders. Archaeological evidence of osteological remains of non-Europeans, animal and plant remains and thousands of objects reveals these world contacts and their importance in the development of a multicultural Europe, one of the most important legacies of this process.

Although these objects could be considered luxury items in Portugal, they seem to have been daily household goods, especially in urban centres. Porcelain and ivory objects were certainly used in everyday activities and the wide spread of semi-precious stone beads suggests similar use. Consequently, even generic Portuguese households reflected some degree of the country's global contacts through direct or proxy evidence of objects, animals, plants and people from around the globe. Unfortunately, there are not that many depictions of what the interior of a house in Early Modern age looked like in Portugal, although archaeology does reveal intramural arrangements and activities. However if interiors are unknown, there a few paintings of Lisbon that reveal how multicultural it was. Portugal's early modern representations reveal a society where people from around the world would gather performing very different activities (Fig. 10).

Although many European scholars have developed projects in the colonies related to colonial encounters or colonial occupations, ${ }^{66}$ these cultural changes did not simply occur in the colonies but were also a fundamental outcome of interaction in European territory itself. Portugal had a privileged position in bringing new cultures into Europe in the Early Modern period. However, it seems to be more than a Portuguese problem that 'the subjects of colonialism or immigration as a major component of globalization have hardly been dealt', since the subject has just recently begun to attract research in continental Europe. ${ }^{67}$ Archaeologists from different countries are approaching globalization processes based 
on their particular methods of research and just recently have they have started to mention Portugal in their publications on global contacts. ${ }^{68}$ This is also uniquely a Portuguese accountability. Several authors have addressed how the diversity of languages in Europe led to the difficulty in establishing European archaeological studies beyond borders. ${ }^{69}$ Until recently, the publication of papers related to Portuguese post-medieval archaeology has been nonexistent, and indeed, despite increased interest, publications are still few. ${ }^{70}$

As a Portuguese person born in the 20th century, just a few years after the 'loss' of the African colonies, I was still taught that Portugal had been the head of an extraordinary empire where wealth from around the world converged into Europe and the country brought civilization to uncivilized populations, creating the perfect crib for social inequality. This narrative was developed during the dictatorship (1933-74) and may be one of the reasons Portuguese scholars took so much time to critically debate concepts related to globalization especially since it would redefine the country's past in a different perspective than the one we were all educated in, still in line with the political orthodoxy of the time, forcing us to decolonize our mentalities before doing it in scientific studies. Strange as it may seem, considering the role of the country in global colonial expansion, the word 'colonialism' has only recently emerged in Portuguese archaeological debates.

\section{ACKNOWLEDGEMENTS}

My first thanks go to the Society for Post-Medieval Archaeology for inviting me to give the Geoff Egan Memorial Lecture in 2019. I met Geoff in 2006 in Exeter for the first time and his work has influenced my research in many different ways.

Talking about all the global interactions of Portugal means I need to express my thanks to everyone that has ever helped me around the world to understand archaeological contexts and the formation of mentalities. That list would occupy many pages and it does not fully express my immense gratitude to everyone who has been there for the past two decades. I leave my thanks to all of you, across the oceans and in different continents in all the places where the Portuguese settled, explored or traded.

\section{FUNDING}

This work is funded by national funds through FCT [DL57/2016/CP1453/CT0084].

\section{NOTES}

${ }^{1}$ Gerritsen \& Riello 2016, 6.

${ }^{2}$ Palma \& Reis 2019

${ }^{3}$ Horning 2016, 111.

${ }^{4}$ Frank 1998.

${ }^{5}$ Shaw 1989; 1998.

${ }^{6}$ Gomes 2012, 13.

${ }^{7}$ Casimiro \& Sequeira 2019.

${ }^{8}$ Alessandrini 2011; 2013; Ribeiro 1990.

${ }^{9}$ Caldeira 2017; Marques 1999.

${ }^{10}$ Phillips 2013; Fracchia 2012; Kaufmann 2017.

${ }^{11}$ Klein 2012.

${ }^{12}$ Horning 2016, 111.

${ }^{13}$ Vogt 1973, 2.

${ }^{14}$ Phillips 2013; Stella 2000.

${ }^{15}$ Henriques 2011.

${ }^{16}$ Martiniano et al. 2014.

${ }^{17}$ Neves et al. 2011; Wasterlain et al. 2016.

${ }^{18}$ Pereira \& Ferro 2011.

${ }^{19}$ The media were very interested in this excavation and photographs can be seen in several newspapers https://www.publico.pt/2019/02/04/local/noticia/ criancas-mazelas-africanos-antigo-cemiterio-bucelasmisterio-1860406

${ }^{20}$ This excavation occurred in 2019 thus all information was provided by Dr Nathalie Ferreira the team's bioanthropologist.

${ }^{21}$ Caldeira 2017; Caldeira \& Feros 2019.

${ }^{22}$ Coelho 2019.

${ }^{23}$ Sweet 2013.

${ }^{24}$ Santana et al. 2015.

${ }^{25}$ Goris \& Marlier 1971; Bassani \& Fagg 1988.

${ }^{26}$ Gomes et al. in press.

${ }^{27}$ Casimiro et al. 2020.

${ }^{28}$ In 1515, King Manuel decided to organize a fight between an elephant and rhinoceros in downtown Lisbon, but the elephant fled in panic and the fight never occurred.

${ }^{29}$ Moreno-García \& Detry 2010; Casimiro et al. 2017a; Crawford 1992.

${ }^{30}$ Braga 2007; 2015.

${ }^{31}$ Davis et al. 2018; Detry \& Pimenta 2017; Sousa et al. 2017; Detry et al. 2014; Davis et al. 2012; Moreno-Garcia \& Detry 2010.

${ }^{32}$ Queiróz 2012.

${ }^{33}$ Castro 2003.

${ }^{34}$ Mearns et al. 2015.

${ }^{35}$ Giorgi 1997; Badura 2003; Castro 2003; Preusza et al. 2015.

${ }^{36}$ Henriques 2012; Krahe 2016; Henriques \& Casimiro 2018.

${ }^{37}$ Canepa 2016; Ostkamp 2014.

${ }^{38}$ Gomes et al. 2015. There seems to be gender related consumption with porcelain in religious houses. While female convents present large quantities of porcelain, in male religious houses the number of Chinese porcelain objects is much less. 
${ }^{39}$ Henriques 2012; Henriques \& Casimiro 2018; Casimiro et al. 2019.

${ }^{40}$ Casimiro \& Santos 2014; Casimiro et al. 2017 b.

${ }^{41}$ Henriques \& Casimiro 2020.

${ }^{42}$ Casimiro 2011.

${ }^{43}$ Gomes et al. 2017, 96.

${ }^{44}$ The Campo das Cebolas archaeological excavation discovered the landfilling of 16th century Lisbon river front where the garbage of that area of the city was thrown for over a century. The collection reveals all the world contacts of Lisbon with Europe, Asia, Africa and South America. Unfortunately there are no plans or research project to study this site.

${ }^{45}$ Casimiro \& Santos 2014

${ }^{46}$ Mearns et al. 2015.

${ }^{47}$ Freire 1914.

${ }^{48}$ Casimiro et al. 2017b; Amaro et al. 2013; Rodrigues et al. 2013; Casimiro \& Barros 2013.

${ }^{49}$ Lima et al. 2012.

${ }^{50}$ Medici 2015.

${ }^{51}$ Henriques et al. 2019.

${ }^{52}$ Ferreira et al. 2018.

53 Intino 1992, 63.

${ }^{54}$ Fontes 2014.

${ }^{55}$ Casimiro et al. $2017 \mathrm{~b}$

${ }^{56}$ Marques \& Fernandes 2006.

${ }^{57}$ Martingil 2017, 435.

${ }^{58}$ Almeida et al. 2017.

${ }^{59}$ Casimiro 2013.

${ }^{60}$ Casimiro \& Newstead 2019a.

${ }^{61}$ Newstead \& Casimiro 2018; Gomes \& Casimiro 2018.

${ }^{62}$ Newstead \& Casimiro 2020; Casimiro \& Newstead 2019b.

${ }^{63}$ Gomes \& Casimiro 2013.

${ }^{64}$ Wilcoxen 1999.

${ }^{65}$ Casimiro 2011.

${ }^{66}$ Evans et al. 2017; Hofman \& Keehnen 2019; Keehnen et al. 2019; Sørensen et al. 2013; Amaro 2012.

${ }^{67}$ Meheler 2013, 40.

${ }^{68}$ Horning 2016.

${ }^{69}$ Meheler 2013, 39.

${ }^{70}$ Gomes \& Casimiro 2013; Teixeira et al. 2015; Tourigny et al. 2019.

\section{BIBLIOGRAPHY}

A Herança do Infante, Lagos: Câmara Municipal de Lagos/Centro de Estudos dos Povos e das Culturas de Expressão Portuguesa $\mathrm{FCH} / \mathrm{UCP} / \mathrm{Centro}$ de História de Além-Mar FCSH/UNL/Uaç.

Actas do Encontro Diz-me o que comes... Alimentação antes e depois da cidade, Lisbon: Centro Arqueologia de Lisboa.

Actas do I Encontro de Arqueologia de Lisboa Uma Cidade em Escavação, Lisbon: Centro Arqueologia de Lisboa.
Alessandrini, N. 2011, 'La presenza genovese a Lisbona negli anni dell unione delle corone (15801640)', in Herrero Sánchez et al. 2011, 73-98.

Alessandrini, N. 2013, 'Indícios, sinais e moradas dos Italianos estantes em Lisboa (séc. XVI)', in Nunziatella et al. 2013, 103-21.

Almeida, A. et al. 2017, 'O Naufrágio Quinhentista do Belinho, Esposende: resultados preliminares', $\mathrm{Al}$ Madan Online 21:3, 80-95.

Amaro, C. et al. 2013, 'Prisão do Aljube no século XVI - vidros, majólica italiana e cerâmica esmaltada espanhola,' in Arnaud et al. 2013, 1019-24.

Amaro, C. 2012, 'Sé da Cidade Velha, República de Cabo verde: resultados da $1^{\text {a }}$ fase de campanhas arqueológicas', in Teixeira \& Bettencourt 2012, 451-64.

Arnaud, J.M. et al. (eds) 2013, Arqueologia em Portugal - 150 anos, Lisbon: Associação dos Arqueólogos Portugueses.

Badura, M. 2003, 'Pimenta officinalis Lindl. (pimento, myrtle pepper) from early modern latrines in Gdańsk (northern Poland)', Veg. Hist. Archaeobot., 12:4, 249-252. doi:10.1007/s00334-003-0023-6

Bassani, E. \& Fagg, W.B. 1988, Africa and the Renaissance: Art in Ivory, New York: The Center for African Art and Prestel-Verlag.

Bouza, F. et al. (eds) 2019, The Iberian World 1450-1820, London: Routledge.

Braga, I. 2007, A herança das Américas em Portugal, Lisbon: CTT.

Braga, I. 2015, 'A Mesa Conventual e os Sabores da América', in Ribeiro \& Soares 2015, 169-82.

Buxeda I. et al. (eds) 2015, Global Pottery 1. Historical Archaeology and Archaeometry for Societies in Contact. Vol. 2761. BAR International Series, Oxford: Hadrain Books.

Caldeira, A.M. 2017, Escravos em Portugal. Das origens ao século XIX, Lisbon: Esfera dos Livros.

Caldeira, A.M. \& Feros, A. 2019, 'Black Africans in the Iberian peninsula (1400-1820)', in Bouza et al. 2019, 261-79.

Canepa, T. 2016, Silk, Porcelain and Lacquer: China and Japan and their Trade with Western Europe and the New World, 1500-1644, London: Paul Holberton Publishing.

Casimiro, T.M. 2011, Portuguese Faience in England and Ireland. Vol. S2301. Brit. Archaeol. Rep. Int. Ser., Oxford: Archaeopress.

Casimiro T.M. 2013, 'From Portugal to Newfoundland in the 17th century: supplying European colonies or provisioning a fishery', in Pope 2013, 224-32.

Casimiro, T.M. \& Barros, L. 2013, 'Majólica Italiana em Almada', An. Almada 15, 47-58.

Casimiro, T.M. et al. 2017a, 'Cozinhar e comer: cerâmicas e alimentação em Carnide (1550-1650)', in Actas do Encontro 2017, 105-16.

Casimiro, T.M. et al. 2017b, "Louça "de fora" em Carnide (1550-1625). Estudo do consumo de cerâmica importada', in Actas do I Encontro, 56-67. 
Casimiro, T.M. et al. 2020, 'Mobility and identities. The case of the so-called African pots (Lisbon)', Int. J. Hist. Archaeol. 24, 79-94. doi:10.1007/ s10761-019-00504-z

Casimiro, T.M. et al. 2019, 'Pottery use and social inequality in mid-18th century Lisbon. An initial approach', in Matejkova et al. 2019, 1-18.

Casimiro, T.M. \& Newstead, S. 2019a, '400 years of water consumption: early modern pottery cups from Portugal', Ophiussa 3, 125-33.

Casimiro, T.M. \& Newstead, S. 2019b, 'Portuguese coarsewares in North Atlantic trade (16th-18th centuries)', Am. Ceram. Circle J. XX, 59-82.

Casimiro, T.M. \& Santos, C. 2014, 'Casa Fidalga (Bordeira, Aljezur)', Al-Rihana 6, 86-98.

Casimiro, T.M. \& Sequeira, J.L. 2019, 'Os deuses devem estar loucos... ou a emergência de uma Arqueologia Contemporânea em Portugal', AlMadan Online 22:3, 88-97.

Castro, F. 2003, 'The Pepper Wreck, an early 17thcentury Portuguese Indiamanat the mouth of the Tagus River, Portugal', Int. J. Naut. Archaeol. 32:1, 6-23. doi:10.1006/ijna.2003.1067

Coelho, R. 2019, 'An archaeology of decolonization: Imperial intimacies in contemporary Lisbon,' $J$. Soc. Archaeol. 19:2, 181-205. doi:10.1177/ 1469605319845971

Crawford, R. 1992, 'Introduction to Europe and diffusion of domesticated turkeys from the America,' Arch. Zootec. 41:154, 307-14.

Davis, S.J. et al. 2012, 'Molecular and osteometric sexing of cattle metacarpals: a case study from 15th century AD Beja, Portugal', J. Archaeol. Sci. 39:5, 1445-54. doi:10.1016/j.jas.2011.12.003

Davis, S.J.M. et al. 2018, 'An osteometrical method for sexing cattle bones: the metacarpals from 17th century Carnide, Lisbon, Portugal,' Ann. Nat. Museums Wien Ser. A 120, 367-87.

Detry, C. \& Pimenta, J. 2017, 'Animal remains from medieval and modern Vila Franca de Xira, Portugal: Excavations at the Neo-Realism Museum', CIRA Arqueol. 5, 238-59.

Detry, C. et al. 2014, 'At table with the nuns: the mammals of 17 th century Santa-Clara-a-Velha Monastery (Coimbra, Portugal)', in Detry \& Dias 2014, 117-28.

Detry, C. \& Dias, R. (eds) 2014, Proceedings of the First Zooarchaeology Conference in Portugal. Brit. Archaeol. Rep. 2662, Oxford: Archaeopress.

Du Tage à la mer de Chine. Une epopée portugaise.

Evans, C. et al. 2017, 'Finding Alcatrazes and early Luso-African settlement on Santiago Island, Cape Verde.' Antiquity 91:358, e8.

Ferreira, L.F. et al. 2018, 'Blue on Blue 16th-17th century Portuguese Ceramics', Archaeometry 60, 1-18. doi:10.1111/arcm.12336

Fontes, L. 2014, Escavações Arqueológicas na Rua D. Paio Mendes, $\mathrm{n}^{\circ}$ 67-75, Braga (unpublished report).
Fracchia, C. 2012, 'The urban slave in Spain and New Spain', in MacGrath \& Massing 2012, 195-216.

Fragmentos de Arqueologia, Extrair e Produzir... Dos primeiros artefactos à Industrialização, Lisbon: Centro Arqueologia de Lisboa.

Frank, A. 1998, ReOrient: Global Economy in the Asian Age, Berkley: University of California Press.

Freire, B. 1914, 'Inventário da Infanta D. Beatriz 1507,' Arch. Hist. Port. IX, 64-110.

Funari, P. \& Senatore, M. (eds) 2015, Archaeology of Culture Contact and Colonialism in Spanish and Portuguese America, Berlin: Springer.

Gaimster, D. \& Stamper, P. (eds) 1997, The Age of Transition. The Archaeology of English Culture 1400-1600, Oxford: Oxbow Books

Gerritsen, A. \& Riello, G. 2016, 'The global lives of things: material culture in the first global age', in Gerritsen \& Riello 2016, 1-28.

Gerritsen, A. \& Riello, G. (eds) 2016, The Global Lives of Things. The Material Culture of Connections in the Early Modern World, New York: Routledge.

Giorgi, J. 1997, 'Diet in Late Medieval and Early Modern London: the archaeobotanical evidence', in Gaimster \& Stamper1997, 197-213.

Gomes, M.V. \& Casimiro, T.M. 2018, 'Montemor-oNovo pottery production. Characteristics and distribution', Medieval Ceram. 37, 11-20.

Gomes, M.V. et al. 2015, 'Convents, monasteries and porcelain: a case study of Santana Convent. Lisbon>', in Buxeda et al. 2015, 93-101.

Gomes, M.V. et al. 2017, 'Objectos produzidos em matérias duras de origem animal do Convento de Santana de Lisboa', in Actas do I Encontro de Arqueologia de Lisboa, 85-105.

Gomes M.V. \& Casimiro T.M. 2013, On the World's Routes. Portuguese Faience (16th-18th centuries), Lisbon: Instituto de Arqueologia e Paleociências.

Gomes, M.V. et al. in press, 'Afro-Portuguese ivories from Sierra Leone and Benin. Archaeological discoveries from Southern Portugal', African Arts.

Gomes, R.V. 2012, 'A Arqueologia da Idade Moderna em Portugal - contributos e problemáticas', $O$ Arqueól. Port. Sér. V, 2, 13-75.

Gomes, R.V. \& Casimiro, T.M. 2013, 'Post-medieval archaeology in Portugal', Post-Medieval Archaeol. Port. 47:1, 17-34. doi:10.1179/0079423613Z. 00000000023

Goris, J.-A. \& Marlier, G. 1971, Albrecht Dürer. Diary of His Journey to the Netherlands, 1520-1521, Greenwich: New York Graphic Society Ltd.

Henriques, I. 2011, Os africanos em Portugal. História e Memória. Séculos XV a XXI, Lisbon: Comité Português do projecto Unesco "A Rota do Escravo".

Henriques, J.P. 2012, 'Do Oriente para Ocidente: Contributo para o conhecimento da porcelana chinesa nos quotidianos de época moderna. Estudo de 
três contextos arqueológicos de Lisboa', in Teixeira \& Bettencourt 2012, 919-32.

Henriques, J.P. \& Casimiro, T.M. 2018, 'Pelo Tejo acima: dois séculos de porcelana em Vila Franca de Xira', Cira Arqueol. 6, 254-69.

Henriques, J.P. \& Casimiro, T.M. 2020, 'Cerâmica oriental em Alhandra', Cira Arqueol. 7.

Henriques, J.P. et al. 2019, 'Vestígios de produção oleira dos finais do século XV (Escadinhas da Barroca, Lisboa)', in Fragmentos de Arqueologia, Extrair e Produzir, 108-20.

Herrero Sánchez, M. et al. Genova y la monarquía hispánica (1528-1713), Genoa: Società Ligure di Stori Patria.

Hofman, C.L. \& Keehnen, F. (eds) 2019, Material Encounters and Indigenous Transformations in the Early Colonial Americas: Archaeological Case Studies, Leiden: Brill.

Horning, A. 2016, 'Transatlantic currents: exploring the past, present and future of global historical archaeology', Hist. Archaeol. 50:3, 111-26. doi:10. 1007/BF03377337

Intino, R. 1992, 'La Découverte de la Chine L'aventure Portugaise', in Du Tage à la mer de Chine. Une epopée portugaise, 53-65.

Kaufmann, M. 2017, Black Tudors, the Untold Story, London: Oneworld Publications.

Keehnen, F. et al. 2019, 'Material Encounters and Indigenous Transformations in the Early Colonial Americas', in Hofman \& Keehnen 2019, 1-31.

Klein, H. 2012, The Atlantic Slave Trade, Cambridge: Cambridge University Press.

Krahe, C. 2016, Chinese Porcelain in Habsburg Spain, Madrid: Centro de Estudios Europa Hispánica.

Lane, P. \& Macdonald, C. (eds) 2013, Slavery in Africa: Archaeology and Memory, Oxford: Oxford University Press.

Lima, A. et al. 2012, 'Chemical analysis of 17 th century Millefiori glasses excavated in the Monastery of Sta. Clara-a-Velha, Portugal: comparison with Venetian and façon-de-Venise production', $J$. Archaeol. Sci. 5, 1238-48. doi:10.1016/j.jas.2012. 01.006

MacGrath, J. \& Massing, M. (eds) 2012. The Slave in European Art: From Renaissance Trophy to Abolitionist Emblem, London: The Warburg Institute.

Marques, A. \& Fernandes, L. 2006, 'Palácio dos Marqueses de Marialva. Intervenção Arqueológica na Praça Luís de Camões (Lisboa, 1999-2000)', Patrim. Estud. 9, 195-206.

Marques, J.P. 1999, Os Sons do Silencio. O Portugal de Oitocentos e a Abolição do Tráfico de Escravos, Lisbon: Imprensa de Ciências Sociais.

Martingil, M. 2017, 'Testemunhos arqueológicos na Rua do Jardim do Regedor $\mathrm{n}^{\text {os }} 18$ a 32, Lisboa', in Actas do I Encontro de Arqueologia de Lisboa 2017, 426-39.
Martiniano, R. et al. 2014, 'Genetic evidence of African slavery at the beginning of the transAtlantic slave trade', Sci. Rep. 4, 5994.

Matejkova, K. \& Blazkova, G. (eds) 2019, Europa Post-Medievalis, Oxford: Archaeopress.

Mearns, D. et al. 2015, 'A Portuguese East Indiaman from the 1502-1503 Fleet of Vasco da Gama off Al Hallanuyah Island, Oman: an interin report', Int. J. Naut. Archaeol. 45:2, 331-51. doi:10.1111/10959270.12175

Medici, T. 2015, Vidros da terra: o vidro tardomedieval e moderno em Portugal (séculos XIV-XVII): o contributo da arqueologia, Coimbra (unpublished $\mathrm{PhD}$ dissertation)

Meheler, N. 2013, 'Globalization, immigration and transformation: thoughts from a European perspective', Hist. Archaeol. 47:1, 38-49.

Moreno-García, M. \& Detry, C. 2010, 'The dietary role of hens, chickens and eggs among a 17th-century monastic order: the Clarisse of Santa Clara-aVelha, Coimbra (Portugal)', Gron. Archaeol. Stud. 12, 45-55.

Newstead, S. \& Casimiro, T.M. 2018, 'Strange adventures in a city made of marble: exploring pottery production in Estremoz, Portugal', Medieval Ceram. 37, 37-45.

Newstead, S. \& Casimiro, T.M. 2020, 'What's that smell? New directions for material studies', Antique.

Neves, M.J. et al. 2011, 'História de um arrabalde durante os séculos XV e XVI: O "Poço dos Negros" em Lagos (Algarve, Portugal) e o seu contributo para o estudo dos escravos africanos em Portugal', in A Herança do Infante 2011, 29-46.

Nunziatella, A. et al. (eds) 2013 Le nove son tanto e tante buone, che dir non se pò Lisboa dos Italianos: História e Arte (sécs. XIV-XVIII), Lisbon: Cátedra de Estudos Sefarditas.

Ostkamp, S. 2014, 'The Dutch 17th-century porcelain trade from an archaeological perspective', in van Campen \& Eliëns 2014, 53-85.

Palma, N. \& Reis, J. 2019, 'From convergence to divergence: Portuguese economic growth, 1527-1850', J. Econ. Hist. 79:2, 477-506. doi:10. 1017/S0022050719000056

Pereira, A. \& Ferro, S. 2011, 'A necrópole de S. Salvador (Sines): Dados Bioarqueológicos', in Sines, o Porto e o Mar, 27-45.

Phillips, W. 2013, Slavery in Medieval and Early Modern Iberia, Philadelphia, University of Pennsylvania Press.

Pope, P. (ed.). 2013, Exploring New World Transitions, Woodbridge: Boydell.

Preusza, M. et al. 2015, 'Exotic spices in flux: Archaeobotanical material from medieval and early modern sites of the Czech Lands (Czech Republic)', Interdiscip. Archaeol. Nat. Sci. Archaeol. VI: 2, 223-236. doi:10.24916/iansa.2015. 2.6 
Queiróz, P. 2012, 'Estudos Arqueobotânicos no Mosteiro de São João de Tarouca (Viseu)', Almadan 17:1, 74-100.

Ribeiro, J. 1990, A Comunidade Britânica do Porto durante as Invasões Francesas 1807-1811, Porto: Fundação Eng. António de Almeida.

Ribeiro, C. \& Soares, C. (eds) 2015, Odisseia dos Sabores da Lusofonia, Coimbra: Imprensa da Universidade de Coimbra

Rodrigues, S. et al. 2013, 'As cerâmicas da Idade Moderna da Fortaleza de Nossa Senhora da Luz, Cascais' in Teixeira \& Bettencourt 2013, 865-76.

Santana, J. et al. 2015, 'The Early Colonial Atlantic World: New insights on the African Diaspora from Isotopic and Ancient DNA Analyses of a Multiethnic 15th-17th Century Burial Population From the Canary Islands, Spain', Am. J. Phys. Anthropol. 159:2, 300-12. doi:10.1002/ajpa.22879

Shaw, L. 1989, Trade, Inquisition and the English Nation in Portugal, 1650-1690, Manchester: Carcanet.

Shaw, L. 1998 The Anglo-Portuguese Alliance and the English Merchants in Portugal, 1654-1810, Aldershot: Ashgate.

Sines, o Porto e o Mar. História e Património, Sines: Câmara Municipal de Sines.

Sørensen, M.L.S. et al. 2013, 'A place of history: archaeology and heritage at Cidade Velha, Cape Verde', in Lane \& Macdonald 2013, 421-42.

Sousa, A.C. et al. 2017, 'Fragmentos do quotidiano no terreiro do real monumento de Mafra (1717-2017)', Actas do II Congresso da Associação dos Arqueólogos portugueses, 1915-34.
Stella, A. 2000, Histoires d'esclaves dans la Peninsule Iberique, Paris: Editions de 1'Ecole des Hautes Etudes en Sciences Sociales.

Sweet, J.H. 2013, 'The hidden histories of African Lisbon', in The Black Urban Atlantic in the Age of the Slave Trade, Philadelphia: University of Pennsylvania Press.

Teixeira, A. \& Bettencourt, J. (eds) 2012, Velhos e Novos Mundos. Estudos de Arqueologia Moderna, Lisbon: Centro de História de Além-Mar.

Teixeira, A.; Bettencourt, A. (eds) 2013, Velhos e Novos Mundos. Estudos de Arqueologia Moderna, Lisboa: Centro de História de Além-Mar FCSH/ UNL e Uaç.

Teixeira, A. et al. 2015, 'The Atlantic expansion and the Portuguese material culture in the early modern age: an archaeological approach', in Funari \& Senatore 2015, 19-38.

Tourigny, E. et al. 2019, 'Global post-medieval/historical archaeology: what's happening around the world 2019?', Post-Medieval Archaeol. 53:3, 419-29. doi:10.1080/00794236.2019.1659589

van Campen, J. \& Eliëns, T. (eds) 2014, Chinese and Japanese porcelain for the Dutch Golden Age, Amsterdam: Zwolle.

Vogt, J. 1973, 'The Lisbon slave house and African trade (1486-1521)', Proc. Am. Philos. Soc. 117:1, 1-16.

Wasterlain, S.N. et al. 2016, 'Dental modifications in a skeletal sample of enslaved Africans found at Lagos (Portugal)', Int. J. Osteoarchaeol. 26:4, 621-32. doi:10.1002/oa.2453

Wilcoxen, C. 1999, 'Seventeenth-century Portuguese Faiança and its presence in Colonial America', Northeast Hist. Archaeol. Soc. Hist. Archaeol. 28, 1-20. doi:10.22191/neha/vol28/iss1/2 